$\begin{array}{ll} & \text { Preprints are preliminary reports that have not undergone peer review. } \\ \text { Research Square } & \text { They should not be considered conclusive, used to inform clinical practice, } \\ \text { or referenced by the media as validated information. }\end{array}$

\title{
The effects of Fe- and Mn-oxides and imogolite in the presence of kaolinite on organic nitrogen mineralization and soil enzyme activities
}

Fatemeh Rakhsh ( $\square$ rakhsh.fatemeh@alumni.znu.ac.ir)

University of Zanjan https://orcid.org/0000-0002-6008-0714

Ahmad Golchin

Paul N. Nelson

Ali Beheshti Al Agha

Research Article

Keywords: Ammonium, Cellulase, Microbial biomass, Nanoparticles, Nitrate, Phosphatase.

Posted Date: February 2nd, 2022

DOI: https://doi.org/10.21203/rs.3.rs-1309927/v1

License: (c) (1) This work is licensed under a Creative Commons Attribution 4.0 International License. Read Full License 


\section{Abstract}

Clay minerals and metal oxides play an important role in controlling the decomposition of soil organic matter and the mineralization of organic nitrogen. To study the effects of clay content and composition on mineralization of organic nitrogen, an incubation experiment was carried out. In the experiment, mineralization of organic nitrogen from alfalfa residues, activities of acid and alkaline phosphatase and CM-cellulase, and microbial biomass nitrogen were measured in mixtures of sand, kaolinite $(0,15,30$ or $45 \%$ ) and non-layered colloids (NLCs, being goethite, manganese oxide or imogolite at a kaolinite:NLC ratio of 1:0, 5:1 or 10:1), with pure sand as the control, which were inoculated with microbes from natural soil and incubated at $23^{\circ} \mathrm{C}$ in the dark at $60 \%$ of water holding capacity for 180 days. Mineralization of organic nitrogen and enzyme activity decreased, but microbial biomass nitrogen increased as the contents of kaolinite and NLCs increased. There was an inverse relationship between the specific surface area of the mixtures and the enzyme activity and mineralization of organic nitrogen. Thus, the decreased mineralization of organic nitrogen, despite an increase in microbial biomass, appears to have been due to inactivation of extracellular enzymes by adsorption to the surfaces of kaolinite and NLCs, and perhaps also decreased accessibility of organic nitrogen substrate molecules due to adsorption. The microbial biomass nitrogen increased as the water holding capacity of the mixtures increased, indicating the importance of water-filled pores for accommodating an active microbial biomass and protecting it from desiccation and predators.

\section{Introduction}

Soil organic nitrogen is the biggest terrestrial pool of nitrogen and mineralization is the source of nitrogen for plants in most ecosystems (Batjes, 1996; 2014). Even in agricultural systems with fertilizer applied it is important. Various assays of mineralizable nitrogen have been shown to predict growth and response to fertilizers (Ros et al., 2011; Curtin et al., 2017), but they are time-consuming and expensive. Also, better management of the nitrogen cycle is crucial for global sustainability for reasons of agricultural production, greenhouse gas emissions, soil acidification and impacts on aquatic ecosystems (Suddick et al., 2013; San Martín, 2021). So, we need a better understanding of the mechanisms of nitrogen cycling, in particular the factors influencing stability and mineralization of organic nitrogen.

Soil microorganisms are responsible for $85-90 \%$ of organic matter decomposition (Lavelle et al., 1993), and microbial biomass supplies about $80 \%$ of soil organic matter (Liang \& Balser, 2011; Schmidt et al., 2011; Miltner et al., 2012). Organic compounds may be resistant to microbial degradation and have a long residence time in soil. This could be due to inherent chemical recalcitrance, inaccessibility of microbial population to organic materials due to physical protection, or stabilization by reaction with clays, metal ions and oxides and other organic molecules. For example, decomposition of organic macromolecules to smaller molecules can lead to reaction with mineral particles and stabilization of organic matter in the soil (Cotrufo et al., 2013; Lehmann \& Kleber, 2015; Basile-Doelsch et al., 2020). However, the relative importance of these mechanisms in the stabilization of organic nitrogen compounds is not clear (KögelKnabner et al., 2008).

Adsorption of organic matter to clay and oxide surfaces is an important chemical protection mechanism in carbon and nitrogen cycles. Several factors such as $\mathrm{pH}$, redox conditions, and characteristics of organic materials and mineral surfaces affect the complexation and the degree of sorption of organic materials by mineral surfaces (Zhu, 1997; Jastrow et al., 2007) and hence the mineralization/immobilization of organic nitrogen (Nikolaidis \& Bidoglio, 2013). In comparison to clay minerals, Al- and Fe-oxides have a greater affinity for soil organic matter due to their higher specific surface area (SSA) and reactivity (Sanjay \& Sugunan, 2008; Wallenstein et al., 2010). For example, goethite has a strong association with dissolved organic matter through ligand exchange reactions resulting in Fe-carboxylate bonding (Kaiser \& Zech, 1999; Chorover \& Amistadi, 2001). In soils, organo-mineral complexes are also formed through the binding of organic ligands with $\mathrm{Fe}^{3+}$ and $\mathrm{Al}^{3+}$ on the exchange sites of clay minerals (Higashi, 1983; Oades, 1988; Boudot et al., 1989). The formation of these complexes stabilizes soil organic matter.

Non-crystalline materials such as allophane have exceptionally large SSA and porosity that results in preservation of organic matter via a combination of retention mechanisms (Mikutta et al., 2009; Kramer et al., 2017). In allophanic soils, organic matter reacts slowly with allophane, and the formation of organicallophane complexes causes organic matter to decompose more slowly than in other soils. In allophanic soils enzymatic activities per unit of organic carbon are less than in other soils (Ross et al., 1982). Mulder et al. (2001) showed that increasing the concentration of Al in the forest floor caused a $30-40 \%$ decrease in the decomposition rate of soil organic matter.

Amino sugars are an important component of soil organic nitrogen. Some studies have suggested that minerals influence the turnover of amino sugars, whereas others have shown that minerals affected the proportion of nitrogen sequestered within microbial biomass but not the cycling of nitrogen through the amino sugar pool (Amelung et al., 2001; Amelung \& Zhang, 2001). So, while abiotic processes influence amino sugar cycling, the mechanisms remain obscure.

Enzymes have a strong affinity for clays and oxides (Burns, 1986; Naidja et al., 2000), which can affect their activity. Clays can affect enzymes in two ways. One is by stabilizing and protecting enzymes, preventing them from being degraded and denatured (Nasseau et al., 2001). As a result, Allison (2006) found that clay minerals, especially allophane, intensified enzymatic activities in young volcanic soils. On the other hand, clays can inhibit the activity of enzymes due to blockage of active sites upon adsorption. Kobayashi and Aomine (1967) and Tietjen and Wetzel (2003) reported a decrease in enzyme activities after the addition of allophanic and montmorillonic clays. Rakhsh and Golchin (2018) showed that enzyme activities decreased significantly as the clay content increased. Marx et al. (2005) and Yan et al. (2010), observed that enzyme activities decreased in a clay-sized fraction of soils. Since adsorption of enzymes on clay surfaces occurs by different mechanisms, its effect on enzyme activities may differ accordingly.

Previous studies have focused on the effect of pure clays or pure minerals on organic matter mineralization and enzyme activity, and our knowledge of these processes in the soil matrix is lacking. Of course, there are some studies on enzyme activity and stabilization of organic matter in natural soils, which are mostly interpreted based on differences in soil texture. Studying the effect of metal oxides on enzyme activity and stabilization of organic nitrogen in natural soils is difficult due to confounding of factors including the type and amount of clay and metal oxides. This research aimed to study the effects of clay

Page 2/13 
content and composition on organic nitrogen mineralization, activities of acid and alkaline phosphatases and CM-cellulase, and microbial biomass nitrogen formation. We did this by studying the decomposition of alfalfa residues in artificial soils with different contents of the kaolinite and the non-layered colloids (NLCs)s goethite, manganese oxide and imogolite.

\section{Materials And Methods}

\subsection{Kaolinite, non-layered colloids (NLCs) and chemical characterization:}

Kaolinite was acquired from Sigma Aldrich company (CAS No. 1318-74-7, EC No. 215-286-4). The <2 $\mu$ m fraction of the kaolinite, which was used in the experiment, was prepared according to the method presented by Rakhsh et al. (2017). Goethite (a-FeOOH) was synthesized by the method reported by Schwertmann and Cornell (2008). A Fe( $\left(\mathrm{NO}_{3}\right)_{3} \cdot 9 \mathrm{H}_{2} \mathrm{O}$ solution was slowly neutralized with the $\mathrm{KOH}$ solution and the precipitate aged at $70^{\circ} \mathrm{C}$ for $60 \mathrm{~h}$. Manganese oxide $\left(\beta-\mathrm{MnO}_{2}\right)$ was prepared by the addition of ethanol to $\mathrm{KMnO} 4$ solution at room temperature (Subramanian et al., 2008). Imogolite $\left(\mathrm{Al}_{2} \mathrm{SiO}_{3}(\mathrm{OH})_{4}\right)$ was synthesized as described by $\mathrm{Kijima}(2010)$. The $\mathrm{Na}_{2} \mathrm{SiO}_{3} .5 \mathrm{H}_{2} \mathrm{O}$ solution was slowly mixed with the $\mathrm{AlCl}_{3}$ solution at room temperature for $20 \mathrm{~min}$. The $\mathrm{pH}$ of the suspension was adjusted to 4 using $\mathrm{NaOH}$ and $\mathrm{HCl}$ solutions and kept at $100^{\circ} \mathrm{C}$ for 4 days. The suspension was centrifuged and imogolite particles were freeze-dried.

For the mixtures, kaolinite: NLC ratios of 10: 1 and 5: 1 were selected based on NLC contents of natural soils being $0-15 \%, 0.25->27 \%$, and $0->20 \%$ for goethite, manganese oxide and imogolite, respectively (Sherman et al., 1949; Yoshinaga \& Aomine, 1962; Farmer et al., 1980; Boonfueng et al., 2005; Saidy et al., 2012; Journet et al., 2014),. The mixtures were prepared by making a suspension with a 10:1 (v: w) ratio of $0.01 \mathrm{M} \mathrm{CaCl}_{2}$ solution to colloid. The suspension was stirred for $24 \mathrm{~h}$ and then centrifuged. The kaolinite-NLC mixtures were collected and washed with deionized water $\left(\mathrm{EC}<100 \mu \mathrm{S} . \mathrm{cm}{ }^{-1}\right)$, freeze-dried and passed through a $210-\mu \mathrm{m}$ sieve (Saidy et al., 2012).

The mineralogy of kaolinite and NLCs was confirmed by X-ray diffraction (D8 ADVANCE/Bruker, Germany) (Fig. S1). The SSA of kaolinite, NLCs and NLC-clay mixtures was determined by nitrogen adsorption at $77 \mathrm{~K}\left(\mathrm{P} / \mathrm{P}_{0}\right.$ range of 0.05 to 0.29$)$ with a BELSORP-MINI II (BEL, Japan). Measurement of SSA and pore volume of the kaolinite and NLC samples was performed in triplicate (Table S1). Images of the kaolinite and NLCs by transmission (TEM) and field emission scanning electron microscopy (FESEM) were collected using a CM 120 microscope (Philips, Eindhoven, Netherlands) and MIRA3 XMU (TESCAN, Brno, Czech Republic) (Figs. S2 and S3), respectively. Additional information is provided in Rakhsh et al. (2020).

The pH (1:5 soil: water) and EC (1:5 soil: water) of kaolinite and NLC-clay mixtures were measured with a glass electrode pH meter (Jenway 3510$)$ and EC meter (Jenway 4510) (Rayment \& Lyons, 2011). Cation exchange capacity (CEC) of the materials was determined using the ammonium acetate ( $\mathrm{pH}=7$ ) method (Mikutta et al., 2006). All measurements had three replications and their means are reported (Table S1).

\subsection{Preparation of artificial soils and inoculum:}

The pure sand (quartz) had a particle size of 0.05-2 mm and was prepared as described by Rakhsh et al. (2017). Before use in the incubation experiment, the alfalfa (Medicago sativa) residues were dried in a fan-forced oven at $55^{\circ} \mathrm{C}$ for $72 \mathrm{~h}$ and then ground through a 1-mm sieve (Rakhsh et al., 2017). The organic carbon and total nitrogen contents of the alfalfa residues were $48.21 \%$ and $3.7 \%$, respectively, and the calculated $\mathrm{C} / \mathrm{N}$ ratio was 13 .

Samples of artificial soils (50 g each) were prepared in triplicate by mixing the pure sand with $0,15,30$, or $45 \%$ (w: w) of the prepared clays, which had kaolinite: NLC ratios of 1:0, 10:1 or 5:1. To perform the incubation experiment, the alfalfa residues were added to artificial soils at the rate of 50 mg. $\mathrm{kg}^{-1}$ equivalent to an organic nitrogen addition of $1.85 \mathrm{mg} \cdot \mathrm{g}^{-1}$ artificial soil.

Water holding capacity of all artificial soils was measured in triplicate using a pressure plate apparatus (Pressure plate and ceramic plate cell, ELE International) (Klute, 1986). The artificial soils were sterilized by autoclaving moist at $120^{\circ} \mathrm{C}$ for three times $2 \mathrm{~h}$. Before incubation, the sterilized soil samples were inoculated with microorganisms by the addition of a solution prepared from natural soil (Rakhsh et al., 2017).

\subsection{The incubation experiment:}

Samples of artificial soils (equivalent to $50 \mathrm{~g}$ oven-dry artificial soil) were placed in incubation jars in triplicate and $5 \mathrm{~mL}$ inoculum together with enough distilled water was added to each jar to evenly wet the sample. The inoculated artificial soil samples were air-dried to prevent over-wetting and then remoistened with distilled water to $60 \%$ of water holding capacity for incubation. To keep the moisture content of the artificial soil samples constant during incubation, distilled water was added to the bottom of the incubation jars, which were sealed. The artificial soils were incubated for a total of 180 days in the dark at $23^{\circ} \mathrm{C}$ (in a constant temperature room) (Rakhsh et al., 2017; Rakhsh \& Golchin, 2018; Rakhsh et al., 2020).

Mineralization of organic nitrogen in the alfalfa residues was studied by measuring the concentrations of $\mathrm{NH}_{4}{ }^{+}-\mathrm{N}$ and $\mathrm{NO}_{3}{ }^{-}-\mathrm{N}^{\text {in }}$ the soil samples on the 15 th, 30 th, 45th, and 60th days of incubation. Activities of acid and alkaline phosphatases and CM-cellulase were determined at 180 days of incubation and microbial biomass nitrogen content was measured at 60 days.

To measure the concentration of $\mathrm{NH}_{4}{ }^{+}-\mathrm{N}_{\text {and }} \mathrm{NO}_{3}{ }^{-}-\mathrm{N}$, a moist soil sample equivalent to $10 \mathrm{~g}$ dry soil was placed in a $250 \mathrm{~mL}$ flask, $100 \mathrm{~mL}$ of $1 \% \mathrm{~K}_{2} \mathrm{SO}_{4}$ was added and the suspension was shaken on a mechanical shaker for $60 \mathrm{~min}$ at $300 \mathrm{rpm}$ (Ika Ks 260/Germany). The sample was then centrifuged at $3000 \mathrm{rpm}$ for $6 \mathrm{~min}$ (Labnet Hermle Z400) and the supernatant filtered $(0.45 \mu \mathrm{m})$. To measure $\mathrm{NH}_{4}{ }^{+} \mathrm{N}$ the filtered extract $(50 \mathrm{~mL})$ was treated with dilute $\mathrm{NaOCl}$ and phenol $+\mathrm{NaOH}$ solution $(4 \mathrm{~mL})$ to convert the ammonium ions to a blue indophenol, whose concentration was determined by measuring absorbance at 630 $\mathrm{nm}$ (UV/VIS Perkin Elmer- lambda 25) after 90 minutes (Alef \& Nannipieri, 1995). To measure $\mathrm{NO}_{3}{ }^{-}-\mathrm{N}_{1} 10 \mathrm{~mL}$ of clear filtrate and $2 \mathrm{~mL}$ of $10 \% \mathrm{H}_{2} \mathrm{SO}_{4}$ were 
transferred to each of two 100 -mL flasks and the volume was adjusted to $100 \mathrm{~mL}$ with $\mathrm{K}_{2} \mathrm{SO}_{4}$ solution and mixed. 2-3 granules of zinc were added to one of the flasks and allowed to stand for $4-5 \mathrm{~h}$ for the reduction of nitrate (control). The absorbance of the samples was measured at $210 \mathrm{~nm}$ against the reagent blank (Alef \& Nannipieri, 1995).

Microbial biomass nitrogen was measured using the fumigation-extraction method. Two samples of moist soil, each equivalent to $5 \mathrm{~g}$ of dry soil, were placed in separate beakers, one of which was used for fumigation and the other kept non-fumigated as a control (Brookes et al., 1985). The fumigated and nonfumigated soil samples were extracted with $25 \mathrm{~mL}$ of $0.5 \mathrm{M} \mathrm{K}_{2} \mathrm{SO}_{4}$ (three replicates). $10 \mathrm{~mL}$ of reducing agent $\left(\mathrm{KCr}\left(\mathrm{SO}_{4}\right)_{2}\right)$ along with $300 \mathrm{mg}$ of pure zinc powder was added to a $250 \mathrm{~mL}$ digestion tube. Then $30 \mathrm{~mL}$ of filtered extract was added to the digestion tube and placed at room temperature for 2 hours. Before starting the digestion, $0.6 \mathrm{~mL}$ of $0.19 \mathrm{M} \mathrm{CuSO}_{4}$ solution and $8 \mathrm{~mL}$ of concentrated $\mathrm{H}_{2} \mathrm{SO}_{4}$ were added to the sample. The samples were homogenized and gently heated to $80^{\circ} \mathrm{C}$ for $2 \mathrm{~h}$ to evaporate the water in the samples. The samples were then heated at $280^{\circ} \mathrm{C}$ for $3 \mathrm{~h}$. The digestion tubes were cooled, then samples were distilled in the presence of $\mathrm{NaOH}$ and $\mathrm{H}_{3} \mathrm{BO}_{3}$ and the concentration of nitrogen was obtained in each sample. A K $\mathrm{EN}_{\mathrm{EN}}$ factor of 0.54 was used to convert the organic nitrogen flush to microbial biomass nitrogen (Joergensen \& Mueller, 1996).

The activities of acid and alkaline phosphatase in soils were determined as described by Tabatabai (1994). $1 \mathrm{~g}$ soil was incubated in a 50-mL test tube with 4 $\mathrm{mL}$ of Modified Universal Buffer ( $\mathrm{pH}=6.5$ for assay of acid phosphatase and $\mathrm{pH}=11$ for assay of alkaline phosphatase) and $1 \mathrm{~mL}$ of $0.025 \mathrm{M}$-nitrophenylphosphate $\left(\mathrm{C}_{6} \mathrm{H}_{6} \mathrm{NO}_{6} \mathrm{P}\right)$ for $1 \mathrm{~h}$ at $37^{\circ} \mathrm{C}$ (Incubator Nuve ES 110-250). The reaction was ended with the addition of $4 \mathrm{~mL}$ of $0.5 \mathrm{M} \mathrm{NaOH}$ and then $1 \mathrm{~mL}$ of $0.5 \mathrm{M}$ $\mathrm{CaCl}_{2}$ solution was added to flocculate the soil. The solution was filtered $(0.42 \mu \mathrm{m})$ and the amount of p-nitrophenol produced during the incubation period was determined in the filtrate by spectrometry at $400 \mathrm{~nm}$ (UV/VIS Perkin Elmer- lambda 25).

The activity of CM-cellulase was measured as described by Schinner and Von Mersi (1990). 5-g soil samples were incubated in $50 \mathrm{~mL}$ test tubes with $15 \mathrm{~mL}$ of $0.7 \%$ sodium carboxymethylcellulose solution and $15 \mathrm{~mL}$ of $2 \mathrm{M}$ sodium acetate solution $(\mathrm{pH}=5.5)$ for $24 \mathrm{~h}$ at $50^{\circ} \mathrm{C}$. After incubation, all tubes were shaken briefly and filtered immediately and $0.5 \mathrm{~mL}$ of filtrate was added to $20 \mathrm{~mL}$ of distilled water in test tubes. In the test tubes, $1 \mathrm{~mL}$ of reagent $A$ and $1 \mathrm{~mL}$ of reagent $B$ was added to $1 \mathrm{~mL}$ of diluted filtrate and the test tubes were sealed, mixed well and retained in a boiling water bath for 15 min (Memmert WNE 45). The test tubes were then cooled in a cold-water bath for $5 \mathrm{~min}, 5 \mathrm{~mL}$ of reagent $\mathrm{C}$ was added to each tube, blended and allowed to stand at room temperature for $60 \mathrm{~min}$ for color development. After $30 \mathrm{~min}$, the amount of glucose produced during the incubation period was quantified in the filtrates by spectrometry at $690 \mathrm{~nm}$ (UV/VIS Perkin Elmer- lambda 25), against the reagent blank (Schinner \& Von Mersi, 1990).

\subsection{Statistical analyses}

The data were analyzed using a one-way ANOVA and means were compared by Duncan's Multiple Range Test (DMRT). Before applying ANOVA, the normality of the data and the homogeneity of variance were checked using Kolmogorov-Smirnov and Levene tests, respectively. For data analysis, the SPSS (Windows version 25.0, SPSS Inc., Chicago, USA) and SAS (version 9.4, SAS Institute Inc., Cary, NC) software were employed.

\section{Results}

\subsection{Mineralization of nitrogen in the alfalfa residues}

Mineralization of organic $\mathrm{N}$ (i.e. production of $\mathrm{NH}_{4}{ }^{+}-\mathrm{N}$ plus $\mathrm{NO}_{3}{ }^{-}-\mathrm{N}$ ) occurred throughout the first 60 days of the incubation and was affected significantly $(\mathrm{p}$ $<0.0001$ ) by the treatments (Table 1). Mineralization rate decreased with increasing clay and NLC content, with the lowest rate occurring in soil with the highest clay content, i.e. $0.8 \%$ of added nitrogen mineralized in soil with $45 \%$ clay comprised of $5: 1$ kaolinite: imogolite (Fig. 1 ), and the highest rate ( $7 \%$ of added nitrogen) occurring in the control (Fig. 1). The soils with imogolite had the lowest mineralization rate (across clay and NLC contents) (Fig. 1). The mineralization of organic nitrogen was closely related to the SSA, with linear regression accounting for $52 \%, 63 \%, 65 \%$, and $61 \%$ of the variations in mineralized nitrogen measured 15, 30, 45, and 60 days after incubation $(p<0.05)$ (Fig. 2).

Table 1

The ANOVA results showing the effects of treatments on mineralized organic nitrogen, microbial biomass nitrogen, acid and alkaline phospl

\begin{tabular}{|c|c|c|c|c|c|c|c|c|c|c|c|c|c|}
\hline \multirow{3}{*}{$\begin{array}{l}\text { Source of } \\
\text { variations }\end{array}$} & \multirow[t]{3}{*}{$\mathrm{df}$} & \multicolumn{8}{|c|}{ Mineralized organic nitrogen \% } & \multirow{2}{*}{\multicolumn{2}{|c|}{$\begin{array}{l}\text { Microbial biomass } \\
\text { nitrogen }\end{array}$}} & \multirow{2}{*}{\multicolumn{2}{|c|}{ Acid phosphatase }} \\
\hline & & \multicolumn{2}{|l|}{15 days } & \multicolumn{2}{|l|}{30 days } & \multicolumn{2}{|l|}{45 days } & \multicolumn{2}{|l|}{60 days } & & & & \\
\hline & & $\begin{array}{l}\mathrm{F} \\
\text { value }\end{array}$ & Prob $>F$ & F value & Prob $>F$ & F value & Prob $>F$ & F value & Prob $>F$ & F value & Prob $>F$ & F value & Prob $>\mathrm{F}$ \\
\hline Treatments & 21 & 967.09 & $<001$ & 1822.28 & $<.001$ & 1831.17 & $<001$ & 1408.84 & $\begin{array}{l}<.001 \\
0.01\end{array}$ & 1251.52 & $<.001$ & 1572.82 & $<.001$ \\
\hline Error & 44 & - & - & - & - & - & - & - & - & - & - & - & - \\
\hline CV (\%) & & 2.38 & & 2.00 & & 2.05 & & 2.28 & & 2.99 & & 3.63 & \\
\hline
\end{tabular}

\subsection{Microbial biomass nitrogen and enzyme activity}

Microbial biomass nitrogen content was significantly affected $(p<0.0001)$ by the treatments $($ Table 1$)$, increasing as clay and NLC contents increased. The content of microbial biomass nitrogen, as a proportion of the nitrogen added in the alfalfa residues, ranged from $4.7 \%$ in the pure sand to $15.5 \%$ in the soils with $45 \%$ clay comprised of 5:1 kaolinite: goethite (Fig. 3). It was highest in the soils containing goethite (across the clay contents) (Fig. 3). The microbial C:N ratio was not significantly affected by the treatments. 
Enzyme activities were significantly affected $(p<0.0001)$ by the treatments (Table 1$)$, decreasing as clay and NLC contents increased. The acid and alkaline phosphatase activities ranged from 55.29 and $48.2 \mu \mathrm{g}$ p-nitrophenyl. $\mathrm{g}^{-1}$ dry soil. $\mathrm{h}^{-1}$ in the soil with $45 \%$ clay comprised of $5: 1$ kaolinite: imogolite to 396.24 and $752.79 \mu \mathrm{g}$ p-nitrophenyl. $\mathrm{g}^{-1}$ dry soil. $\mathrm{h}^{-1}$ in the pure sand, respectively (Figs. 4 and 5). Activity of CM-cellulase was similarly affected by the treatments (Fig. 6). Among the NLCs, the lowest and highest enzyme activity was measured in soils with imogolite and goethite (across the clay and NLC contents), respectively (Figs. 4-6). In general, the presence of NLCs reduced the activity of enzymes. Second to the pure sand, the highest enzyme activity was observed in soils containing the kaolinite, but not NLCs (all three kaolinite contents) (Figs. 4-6). The effects of the treatments on the activity of enzymes were related to the SSA non-linearly (Fig. 7).

\section{Discussion}

Mineralization of organic nitrogen (Fig. 1) and the activity of enzymes (Figs. 4-6) decreased as the content of clay increased. In contrast, soils with higher contents of clay had higher contents of microbial biomass nitrogen (Fig. 3). The decreased enzymatic activity with increasing soil clay content shown in this study may be one of the reasons for the reduction of organic nitrogen mineralization in high clay soils. Additionally, the adsorption of organic substrates containing nitrogen may decrease microbial access. Thereby mineralization of organic nitrogen was reduced. The adsorption capacity of soils for nitrogenous compounds depends on the type and content of clay, and the chemistry of nitrogenous compounds (Nikolaidis \& Bidoglio, 2013). Also, this research showed that mineralization of organic nitrogen, enzyme activities and microbial biomass nitrogen contents were influenced by NLC types and contents (Figs. 1-7).

The close correlation of organic nitrogen and carbon mineralization with soil SSA in this study (Fig. 2) and our previous research (Rakhsh et al., 2020), as well as an inverse relationship between SSA of mixtures and enzymatic activity, implies that the influence of clay type and content (texture) on the mineralization of organic carbon and nitrogen and enzyme activities are imposed through the surface supplied by soil for adsorption. The interaction of clay minerals and extracellular enzymes results in the adsorption, the intensity of which is determined by the chemical structure of the enzymes and the SSA, surface charge and cation exchange capacity of the clays. The activity of enzymes decreases when they are bound to clay surfaces as adsorption blocks their active sites or causes deforms them (Zimmerman et al., 2011; Olagoke et al., 2019). Nevertheless, the activity of enzymes can be intensified or at least maintained if binding to clay surfaces stabilizes their structure and allows them to retain their catalytic activities (Sanjay \& Sugunan, 2008). In fact, most of the activity of some enzymes in the soil may be related to stabilized forms rather than free forms (Marx et al., 2005; Schimel et al., 2017). Soil-stabilized enzymes may be considered as an important reservoir of enzymatic activity that acts when the substrate becomes available and stimulates the soil microbial community. In addition, it enables decomposition of various compounds in the soil when enzyme production by the microbial community is low or not possible due to environmental stresses (Stursova \& Sinsabaugh, 2008). Olagoke et al. (2019) studied the effects of montmorillonite content on the activity of extracellular enzymes and showed that the catalytic activity of $a$-glucosidase reduced by $76 \%$ as the content of montmorillonite increased from 0 to $10 \%$. These results are consistent with the effects of kaolinite content in our study.

Earlier work has shown effects of oxides on enzyme adsorption and activity but our work showed that the effects were largely explained by SSA, irrespective of mineralogy. The presence of oxides and hydroxides of Fe, Al and Mn may alter the adsorption of enzymes on clay surfaces (Rao \& Gianfreda, 2000; Rao et al., 2000). For example, the presence of Al-hydroxide on montmorillonite surfaces resulted in lower activity of urease, invertase and tyrosinase but higher activity of phosphatase (Rao et al., 1996; Gianfreda et al., 2002). In our study, the presence of goethite, manganese oxide and imogolite decreased the activity of all enzymes examined (acid and alkaline phosphatase and CM-cellulase) compared to pure kaolinite (Figs. 4-6). Imogolite had the largest effect and goethite the smallest. The effect of manganese oxide was close to that of imogolite (Figs. 4-6). Olagoke et al. (2020) reported that soil weathering and the formation of secondary and pedogenic minerals alter the mineralogical composition of soils and affect soil microbial processes by altering enzymatic activity. Our findings suggest that this effect occurs mostly due to an increase in the number of adsorption sites and the amount of surface area available for adsorption of enzymes.

Contradictory results have been reported for the effect of clay content on the content of microbial biomass carbon and nitrogen in soils, some showing a positive effect (Rakhsh et al., 2020) and others a negative effect (Liddle et al., 2020). This discrepancy is probably related to the size distribution of pores in soils. The positive relationship between microbial biomass carbon and clay content has been attributed to physical protection of microbial biomass by clays (Ladd et al., 1996). The microbial biomass nitrogen increased as the water holding capacities of mixtures increased (Fig. 8), indicating that water-filled pores play an important role in protecting microbial biomass from desiccation and predators. It is important to note that microbes are only active if they are surrounded by soil water and that organic matter breakdown occurs in pore water. A larger quantity of soil water means therefore a larger space in which microbes can be active, mineralize organic matter, grow and incorporate nitrogen into their biomass. These results also suggest that the presence of more microbial biomass does not necessarily mean more microbial degradation as long as the extracellular enzymes secreted by soil microorganisms are inactivated through the adsorption to the surfaces of inorganic colloids.

The protection of soil organic matter by fine particles and reduction in the amount of carbon and nitrogen mineralized in fine textured soils are well known (Sorensen, 1981; Cai et al., 2016; Rakhsh et al., 2017; Rakhsh \& Golchin, 2018; Rakhsh et al., 2020; Riaz \& Marschner, 2020). As the clays enhance the formation of aggregates and provide more surfaces for adsorption, physical protection of organic nitrogen through the occlusion within aggregates inaccessible to soil microorganisms and/or adsorption onto the clay surfaces may have been partially responsible for the reduced nitrogen mineralization in soils with high clay content. Organic matter can adsorb to the surface of clays (Tisdall \& Oades, 1982) as a result, the organic carbon in the fine pores associated with clay minerals is not available for soil organisms (Elliott \& Coleman, 1988). Comparison of diameters of pores in clay and sandy soils with the diameters of bacteria and fungi clearly shows this. The diameters of pores in sandy soils were in the range of 6-30 $\mu \mathrm{m}$ and clay soils in the range of 0.2-1.2 $\mu \mathrm{m}$ (Hassink et al., 1993a; Hassink et al., 1993b). Whereas the diameters of bacteria and fungi are about 0.5 and $5 \mu \mathrm{m}$, respectively (Bae et al., 1972).

The formation of the Al-organic matter complexes probably provides a mechanism for the stability of organic matter against microbial decomposition. Increasing the initial aluminum-to-carbon ratio to more than 0.1 resulted in the reduction of organic matter mineralization by more than $50 \%$ (Schwesig et al., 
2003). In the presence of amorphous Fe-rich materials and $\mathrm{Fe}^{3+}$, organic matter is preserved against microbial decomposition, but the inhibitory effect of $\mathrm{Al}$ is more than that of $\mathrm{Fe}$ (Boudot et al., 1989). The effect of $\mathrm{Al}$ is partially due to toxicity of $\mathrm{Al}^{3+}$, which leads to reduced growth and impaired respiration rate of microorganisms (IIImer \& Erlebach, 2003; Heckman et al., 2013). Our study results show that nitrogen mineralization decreased in the presence of NLCs. In the presence of imogolite, organic nitrogen decomposition was less than goethite and manganese oxide. Probably Al in imogolite led to reduced activity of microorganisms. Aomine and Kobayashi (1964) observed that the microbial breakdown of cellulose and albumin in Andisols containing allophane was less than Alfisols containing illite and montmorillonite.

In the present study, organic nitrogen mineralization decreased with increasing soil clay content, but the content of microbial biomass nitrogen increased, indicating that there were sufficient fine pores protecting organic nitrogen from microbial decomposition and also larger pores to protect microbial biomass from predators and desiccation. Incorporation of a higher proportion of soil total nitrogen into microbial biomass, better protection of microbial biomass from grazing and desiccation, and lower specific microbial respiration in the finer-textured soils also has been reported as the reasons for the higher content of microbial biomass nitrogen in fine-textured soils (Bauhus \& Pare, 1998).

\section{Conclusions}

Silicate Clays and NLCs are among the active components of soil that play a key role in the dynamics of organic nitrogen and its persistence in soil. However, their simultaneous presence in the soil makes it difficult to examine the contribution of each of them to organic nitrogen persistence. Increasing the amount of silicate clays and NLCs in the soil increases the reactive surface area and thus the interactions of organic nitrogen and extracellular enzymes with these clay minerals. It seems that increased SSA, due to increased clay content or the addition of NLCs to pure kaolinite, increased the physical protection of organic matter through the inactivation of enzymes, despite the increase in microbial biomass. The enzyme activities decreased sharply with increasing SSA of the mixtures. The reduced enzyme activity in mixtures with high SSA reduced the decomposition of organic matter, and thus the mineralization of organic nitrogen. The microbial biomass nitrogen increased as the water holding capacities and SSA of the mixtures increased, indicating that water-filled pores play an important role in protecting microbial biomass from desiccation and predators. It is important to note that microbes are active only if they are surrounded by soil water and that organic matter breakdown occurs in pore water. A larger quantity of soil water means therefore a larger space in which microbes can be active, mineralize organic matter, grow and incorporate nitrogen into their biomass. These results also suggest that the presence of more microbial biomass does not necessarily mean more microbial degradation, as long as the extracellular enzymes secreted by soil microorganisms are inactivated through the adsorption to the surfaces of inorganic and/or organic colloids. One of the reasons for the low microbial biomass in soils with imogolite is the presence of Al, which is toxic to microorganisms.

\section{Declarations}

\section{Declaration of competing interest:}

The authors declare that they have no known competing financial interests or personal relationships that could have appeared to influence the work reported in this paper, also, this research did not receive any specific grant from funding agencies in the public, commercial, or not-for-profit sectors.

\section{References}

1. Alef K, Nannipieri P (1995) Methods in Applied Soil Microbiology and Biochemistry. Academic Press

2. Allison SD (2006) Soil minerals and humic acids alter enzyme stability: implications for ecosystem processes. Biogeochemistry 81:361-373

3. Amelung W, Miltner A, Zhang X, Zech W (2001) Fate of microbial residues during litter decomposition as affected by minerals. Soil Sci 166:598-606

4. Amelung W, Zhang X (2001) Determination of amino acid enantiomers in soils. Soil Biol Biochem 33:553-562

5. Aomine S, Kobayashi Y (1964) Effects of allophane on the enzymatic activity of a protease. Soil Science and Plant Nutrition 10:28-32

6. Bae H, Cota-Robles E, Casida L (1972) Microflora of soil as viewed by transmission electron microscopy. Appl Microbiol 23:637-648

7. Basile-Doelsch I, Balesdent J, Pellerin S (2020) Reviews and syntheses: The mechanisms underlying carbon storage in soil. Biogeosciences 17:52235242

8. Batjes NH (1996) Total carbon and nitrogen in the soils of the world. Eur J Soil Sci 47:151-163

9. Batjes NH (2014) Total carbon and nitrogen in the soils of the world. Eur J Soil Sci 65:10-21

10. Bauhus J, Pare D (1998) Effects of tree species, stand age and soil type on soil microbial biomass and its activity in a southern boreal forest. Soil Biol Biochem 30:1077-1089

11. Boonfueng T, Axe L, Xu Y (2005) Properties and structure of manganese oxide-coated clay. J Colloid Interface Sci 281:80-92

12. Boudot JP, Hadj AB, Steiman R, Seigle-Murandi F (1989) Biodegradation of synthetic organo-metallic complexes of iron and aluminium with selected metal to carbon ratios. Soil Biol Biochem 21:961-966

13. Brookes PC, Landman A, Pruden G, Jenkinson DS (1985) Chloroform fumigation and the release of soil nitrogen: A rapid direct extraction method to measure microbial biomass nitrogen in soil. Soil Biol Biochem 17:837-842

14. Burns RG (1986) Interaction of enzymes with soil mineral and organic colloids. Interactions of soil minerals with natural organics and microbes 17:429451

15. Cai A, Feng W, Zhang W, Xu M (2016) Climate, soil texture, and soil types affect the contributions of fine-fraction-stabilized carbon to total soil organic carbon in different land uses across China. J Environ Manage 172:2-9 
16. Chorover J, Amistadi MK (2001) Reaction of forest floor organic matter at goethite, birnessite and smectite surfaces. Geochim Cosmochim Acta 65:95109

17. Cotrufo MF, Wallenstein MD, Boot CM, Denef K, Paul E (2013) The Microbial Efficiency-Matrix Stabilization (MEMS) framework integrates plant litter decomposition with soil organic matter stabilization: do labile plant inputs form stable soil organic matter? Glob Change Biol 19:988-995

18. Curtin D, Beare MH, Lehto K, Tregurtha C, Qiu W, Tregurtha R, Peterson M (2017) Rapid assays to predict nitrogen mineralization capacity of agricultural soils. Soil Sci Soc Am J 81:979-991

19. Elliott ET, Coleman DC (1988) Let the soil work for us. Ecological bulletins 39:23-32

20. Farmer V, Russell J, Berrow M (1980) Imogolite and proto-imogolite allophane in spodic horizons: evidence for a mobile aluminium silicate complex in podzol formation. J Soil Sci 31:673-684

21. Gianfreda L, Rao M, Sannino F, Saccomandi F, Violante A (2002) Enzymes in soil: properties, behavior and potential applications. Developments in soil science. Elsevier, pp 301-327

22. Hassink J, Bouwman L, Zwart K, Bloem J, Brussaard L (1993a) Relationships between soil texture, physical protection of organic matter, soil biota, and C and $\mathrm{N}$ mineralization in grassland soils. Soil Structure/Soil Biota Interrelationships. Elsevier, pp 105-128

23. Hassink J, Bouwman LA, Zwart KB, Brussaard L (1993b) Relationships between habitable pore space, soil biota and mineralization rates in grassland soils. Soil Biol Biochem 25:47-55

24. Heckman K, Welty-Bernard A, Vazquez-Ortega A, Schwartz E, Chorover J, Rasmussen C (2013) The influence of goethite and gibbsite on soluble nutrient dynamics and microbial community composition. Biogeochemistry 112:179-195

25. Higashi T (1983) Characterization of Al/Fe-humus complexes in dystrandepts through comparison with synthetic forms. Geoderma $31: 277-288$

26. Illmer P, Erlebach C (2003) Influence of Al on growth, cell size and content of intracellular water of Arthrobacter sp. PI/1-95. Antonie Van Leeuwenhoek 84:239-246

27. Jastrow JD, Amonette JE, Bailey VL (2007) Mechanisms controlling soil carbon turnover and their potential application for enhancing carbon sequestration. Clim Change 80:5-23

28. Joergensen RG, Mueller T (1996) The fumigation-extraction method to estimate soil microbial biomass: Calibration of the kEN value. Soil Biol Biochem 28:33-37

29. Journet E, Balkanski Y, Harrison SP (2014) A new data set of soil mineralogy for dust-cycle modeling. Atmos Chem Phys 14:3801-3816

30. Kaiser K, Zech W (1999) Release of natural organic matter sorbed to oxides and a subsoil. Soil Sci Soc Am J 63:1157-1166

31. Kijima T (2010) Inorganic and Metallic Nanotubular Materials: Recent Technologies and Applications. Springer Science and Business Media

32. Klute A (1986) Water Retention: Laboratory Methods. Methods of Soil Analysis: part 1-Physical and Mineralogical Methods. Soil Science Society of America, American Society of Agronomy, pp 635-662

33. Kobayashi Y, Aomine S (1967) Mechanism of inhibitory effect of allophane and montmorillonite on some enzymes. Soil Science and Plant Nutrition 13:189-194

34. Kögel-Knabner I, Guggenberger G, Kleber M, Kandeler E, Kalbitz K, Scheu S, Eusterhues K, Leinweber P (2008) Organo-mineral associations in temperate soils: Integrating biology, mineralogy, and organic matter chemistry. J Plant Nutr Soil Sci 171:61-82

35. Ladd J, Van Gestel M, Monrozier LJ, Amato M (1996) Distribution of organic 14C and 15N in particle-size fractions of soils incubated with 14C, 15Nlabelled glucose/ $\mathrm{NH} 4$, and legume and wheat straw residues. Soil Biol Biochem 28:893-905

36. Lavelle P, Blanchart E, Martin A, Martin S, Spain A (1993) A hierarchical model for decomposition in terrestrial ecosystems: application to soils of the humid tropics.Biotropica, $130-150$

37. Lehmann J, Kleber M (2015) The contentious nature of soil organic matter. Nature 528:60-68

38. Liang C, Balser TC (2011) Microbial production of recalcitrant organic matter in global soils: implications for productivity and climate policy. Nat Rev Microbiol 9:75-75

39. Liddle K, McGonigle T, Koiter A (2020) Microbe Biomass in Relation to Organic Carbon and Clay in Soil. Soil Systems 4:41

40. Marx M-C, Kandeler E, Wood M, Wermbter N, Jarvis S (2005) Exploring the enzymatic landscape: distribution and kinetics of hydrolytic enzymes in soil particle-size fractions. Soil Biol Biochem 37:35-48

41. Miltner A, Bombach P, Schmidt-Brücken B, Kästner M (2012) SOM genesis: microbial biomass as a significant source. Biogeochemistry 111:41-55

42. Naidja A, Huang P, Bollag JM (2000) Enzyme-clay interactions and their impact on transformations of natural and anthropogenic organic compounds in soil. J Environ Qual 29:677-691

43. Nasseau M, Boublik Y, Meier W, Winterhalter M, Fournier D (2001) Substrate-permeable encapsulation of enzymes maintains effective activity, stabilizes against denaturation, and protects against proteolytic degradation. Biotechnol Bioeng 75:615-618

44. Nikolaidis NP, Bidoglio G (2013) Soil Organic Matter Dynamics and Structure. Sustainable Agriculture Reviews. Springer, pp 175-199

45. Oades JM (1988) The retention of organic matter in soils. Biogeochemistry 5:35-70

46. Olagoke FK, Kaiser K, Mikutta R, Kalbitz K, Vogel C (2020) Persistent Activities of Extracellular Enzymes Adsorbed to Soil Minerals. Microorganisms 8:1796

47. Olagoke FK, Kalbitz K, Vogel C (2019) Control of Soil Extracellular Enzyme Activities by Clay Minerals-Perspectives on Microbial Responses. Soil Systems 3:64

Page $7 / 13$ 
48. Rakhsh F, Golchin A (2018) Carbohydrate concentrations and enzyme activities as influenced by exchangeable cations, mineralogy and clay content. Appl Clay Sci 163:214-226

49. Rakhsh F, Golchin A, Al Agha AB, Alamdari P (2017) Effects of exchangeable cations, mineralogy and clay content on the mineralization of plant residue carbon. Geoderma 307:150-158

50. Rakhsh F, Golchin A, Al Agha AB, Nelson PN (2020) Mineralization of organic carbon and formation of microbial biomass in soil: Effects of clay content and composition and the mechanisms involved. Soil Biol Biochem 151:108036

51. Rao MA, Gianfreda L (2000) Properties of acid phosphatase-tannic acid complexes formed in the presence of Fe and Mn. Soil Biol Biochem 32:19211926

52. Rao MA, Gianfreda L, Palmiero F, Violante A (1996) Interactions of acid phosphatase with clays, organic molecules and organo-mineral complexes1. Soil Sci 161:751-760

53. Rao MA, Violante A, Gianfreda L (2000) Interaction of acid phosphatase with clays, organic molecules and organo-mineral complexes: kinetics and stability. Soil Biol Biochem 32:1007-1014

54. Rayment GE, Lyons DJ (2011) Soil Chemical Methods. CSIRO Publishing, Australasia

55. Riaz M, Marschner P (2020) Sandy Soil Amended with Clay Soil: Effect of Clay Soil Properties on Soil Respiration, Microbial Biomass, and Water Extractable Organic C. Journal of Soil Science and Plant Nutrition 20:2465-2470

56. Ros G, Temminghoff E, Hoffland E (2011) Nitrogen mineralization: a review and meta-analysis of the predictive value of soil tests. Eur J Soil Sci 62:162173

57. Ross DJ, Tate KR, Cairns A (1982) Biochemical changes in a yellow-brown loam and a central gley soil converted from pasture to maize in the Waikato area.New Zealand journal of agricultural research,35-42

58. Saidy AR, Smernik RJ, Baldock JA, Kaiser K, Sanderman J, Macdonald LM (2012) Effects of clay mineralogy and hydrous iron oxides on labile organic carbon stabilisation. Geoderma 173:104-110

59. San Martín W (2021) Global nitrogen in sustainable development: four challenges at the Interface of science and policy.Life on Land,485-499

60. Sanjay G, Sugunan S (2008) Acid activated montmorillonite: an efficient immobilization support for improving reusability, storage stability and operational stability of enzymes. J Porous Mater 15:359-367

61. Schimel J, Becerra CA, Blankinship J (2017) Estimating decay dynamics for enzyme activities in soils from different ecosystems. Soil Biol Biochem 114:5-11

62. Schinner F, Von Mersi W (1990) Xylanase, CM-cellulase and invertase activity in soil: an improved method. Soil Biol Biochem 22:511-515

63. Schmidt MW, Torn MS, Abiven S, Dittmar T, Guggenberger G, Janssens IA, Kleber M, Kögel-Knabner I, Lehmann J, Manning DA (2011) Persistence of soil organic matter as an ecosystem property. Nature 478:49-56

64. Schwertmann U, Cornell RM (2008) Iron Oxides in the Laboratory: Preparation and Characterization. John Wiley and Sons

65. Schwesig D, Kalbitz K, Matzner E (2003) Effects of aluminium on the mineralization of dissolved organic carbon derived from forest floors. Eur J Soil Sci 54:311-322

66. Sherman GD, Tom AK, Fujimoto CK (1949) The origin and composition of pyrolusite concretions in Hawaiian soils. Pac Sci 3:120-123

67. Sorensen LH (1981) Carbon-nitrogen relationships during the humification of cellulose in soils containing different amounts of clay. Soil Biol Biochem 13:313-321

68. Stursova M, Sinsabaugh RL (2008) Stabilization of oxidative enzymes in desert soil may limit organic matter accumulation. Soil Biol Biochem 40:550553

69. Subramanian V, Zhu H, Wei B (2008) Alcohol-assisted room temperature synthesis of different nanostructured manganese oxides and their pseudocapacitance properties in neutral electrolyte. Chem Phys Lett 453:242-249

70. Suddick EC, Whitney P, Townsend AR, Davidson EA (2013) The role of nitrogen in climate change and the impacts of nitrogen-climate interactions in the United States: foreword to thematic issue. Biogeochemistry 114:1-10

71. Tabatabai M (1994) Soil Enzymes. In: Weaver RW (ed) Methods of Soil Analysis. Soil Science Society of America

72. Tietjen T, Wetzel RG (2003) Extracellular enzyme-clay mineral complexes: Enzyme adsorption, alteration of enzyme activity, and protection from photodegradation. Aquat Ecol 37:331-339

73. Tisdall JM, Oades JM (1982) Organic matter and water-stable aggregates in soils. Eur J Soil Sci 33:141-163

74. Wallenstein M, Allison SD, Ernakovich J, Steinweg JM, Sinsabaugh R (2010) Controls on the temperature sensitivity of soil enzymes: a key driver of in situ enzyme activity rates. Soil enzymology. Springer, pp 245-258

75. Yan J, Pan G, Li L, Quan G, Ding C, Luo A (2010) Adsorption, immobilization, and activity of $\beta$-glucosidase on different soil colloids. J Colloid Interface Sci 348:565-570

76. Yoshinaga N, Aomine S (1962) Imogolite in some Ando soils. Soil Science and Plant Nutrition 8:22-29

77. Zhu Z-L (1997) Mineralization of soil nitrogen. Nitrogen in soils of China. Springer, pp 43-66

78. Zimmerman AR, Gao B, Ahn M-Y (2011) Positive and negative carbon mineralization priming effects among a variety of biochar-amended soils. Soil Biol Biochem 43:1169-1179

\section{Figures}

Page $8 / 13$ 


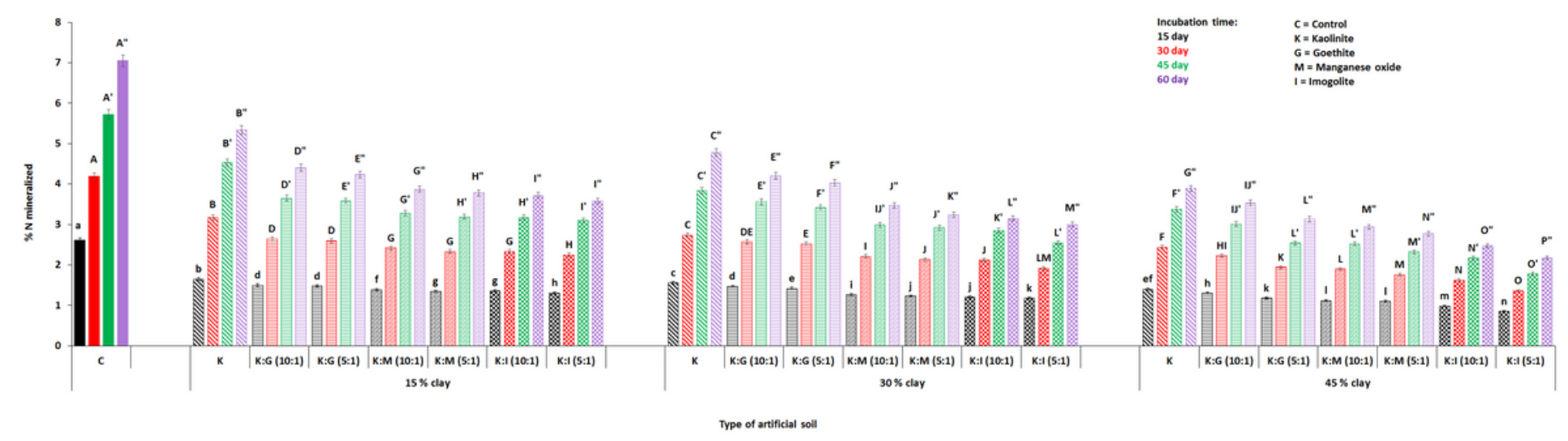

Figure 1

Caption not included with this version.
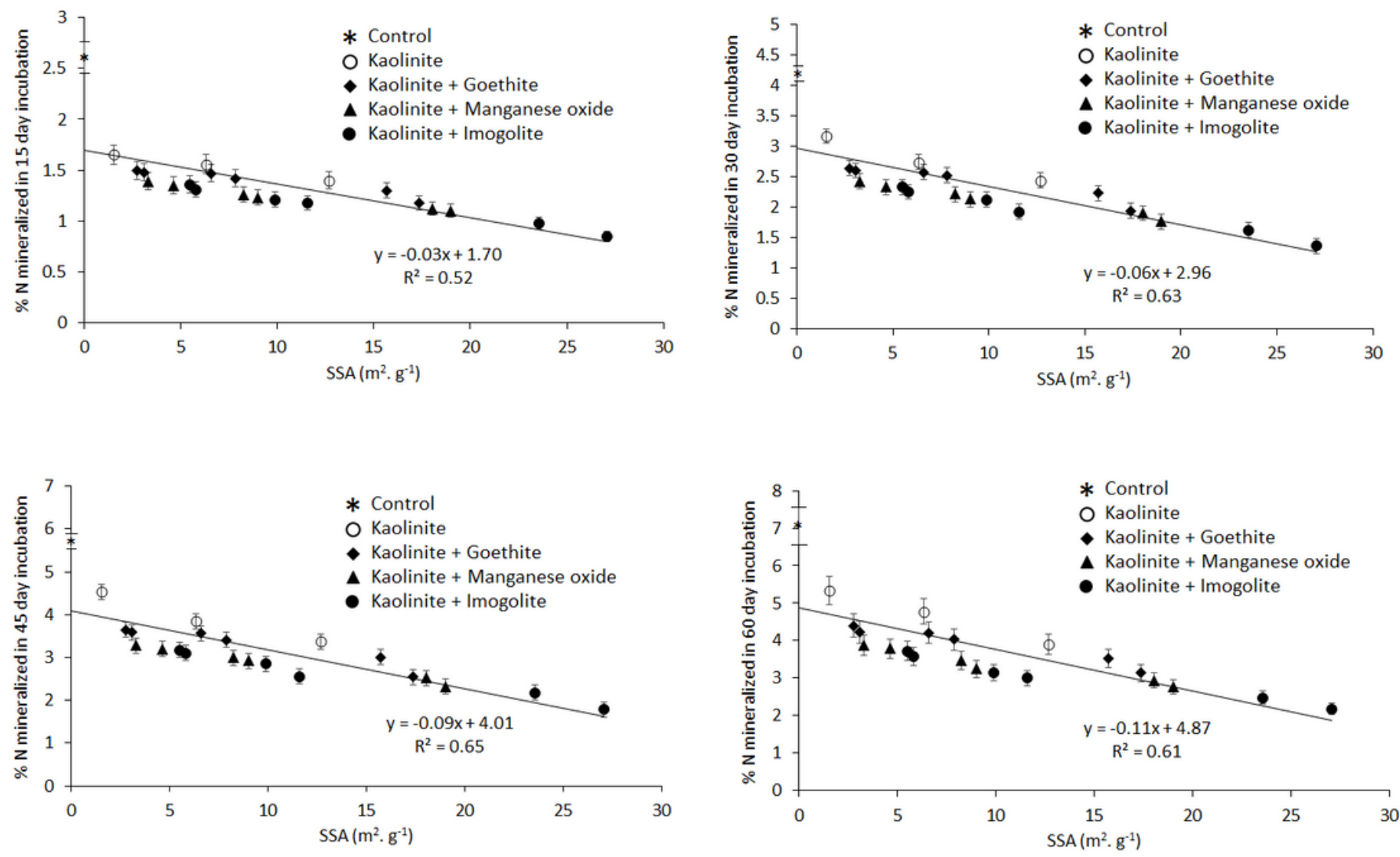

Figure 2

Caption not included with this version. 


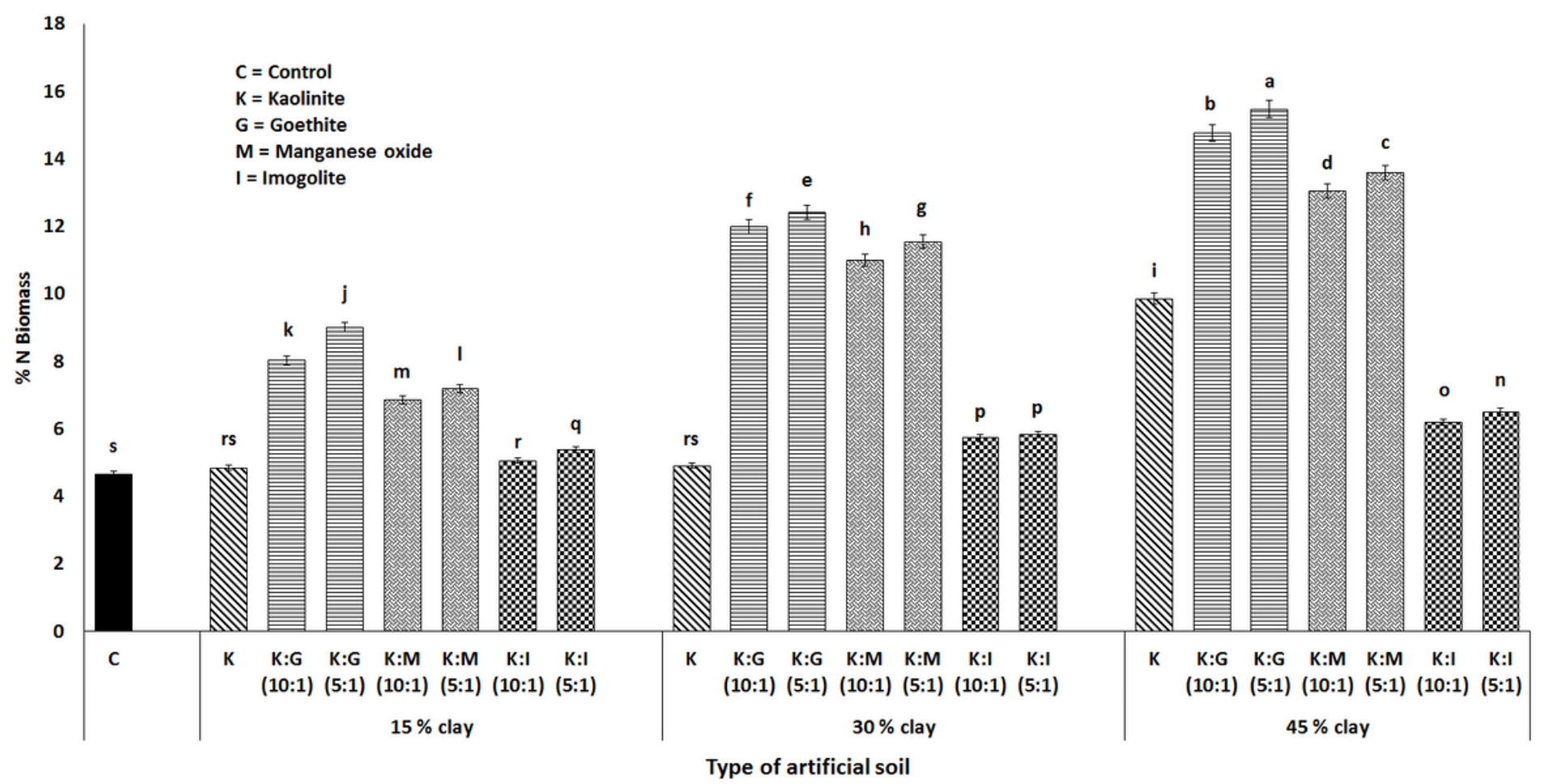

Figure 3

Caption not included with this version.

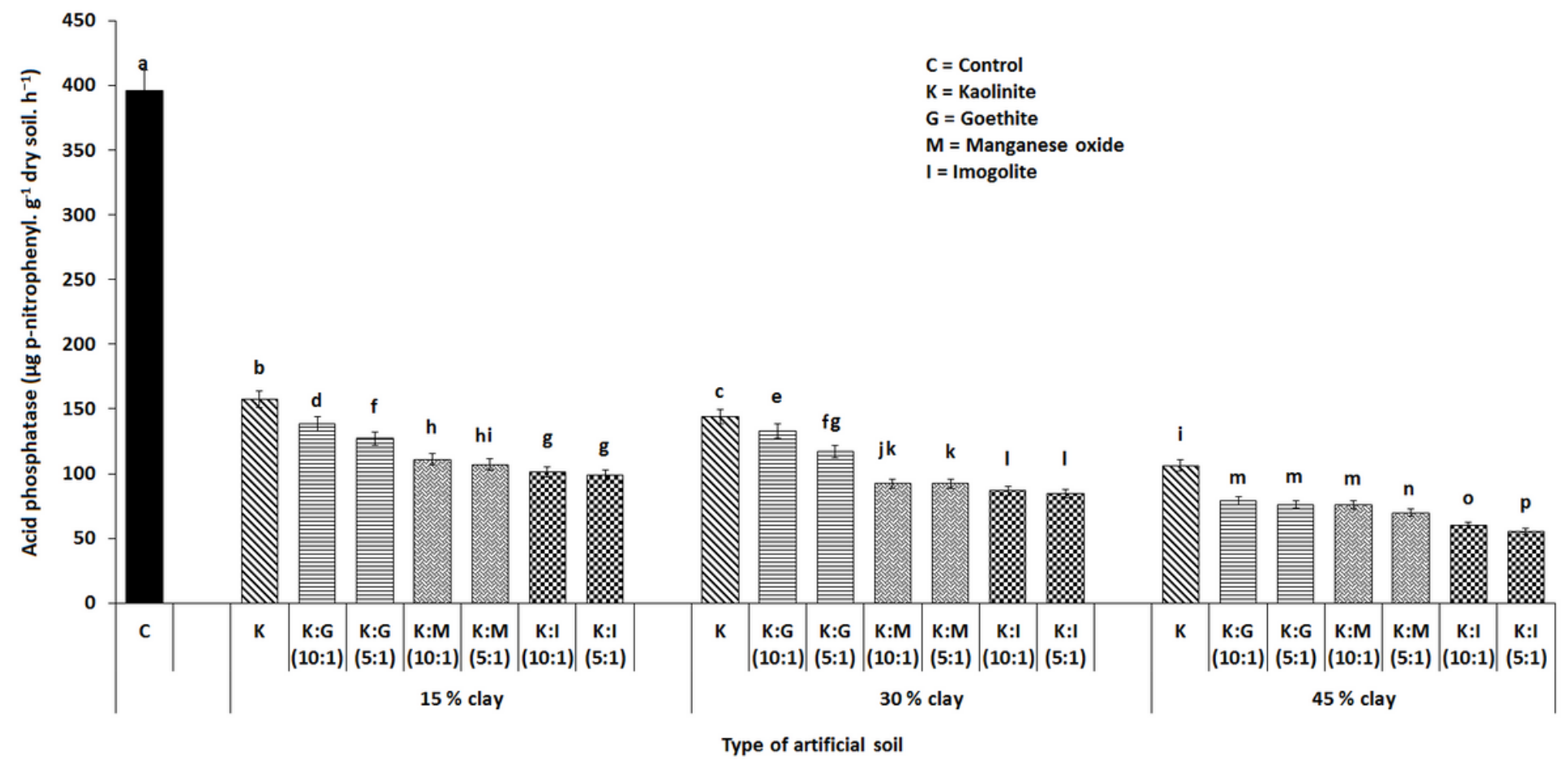

Figure 4

Caption not included with this version. 


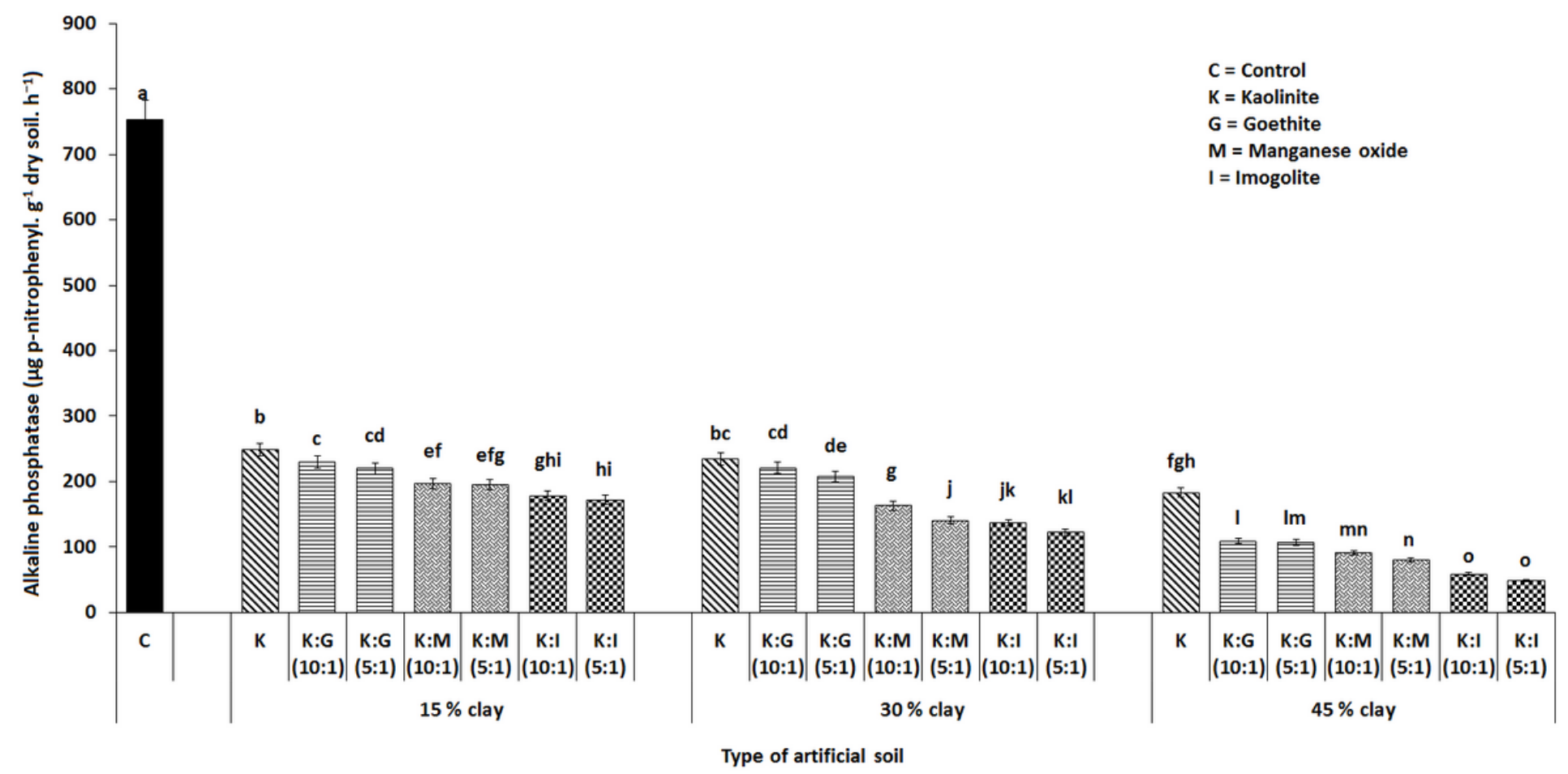

Figure 5

Caption not included with this version.

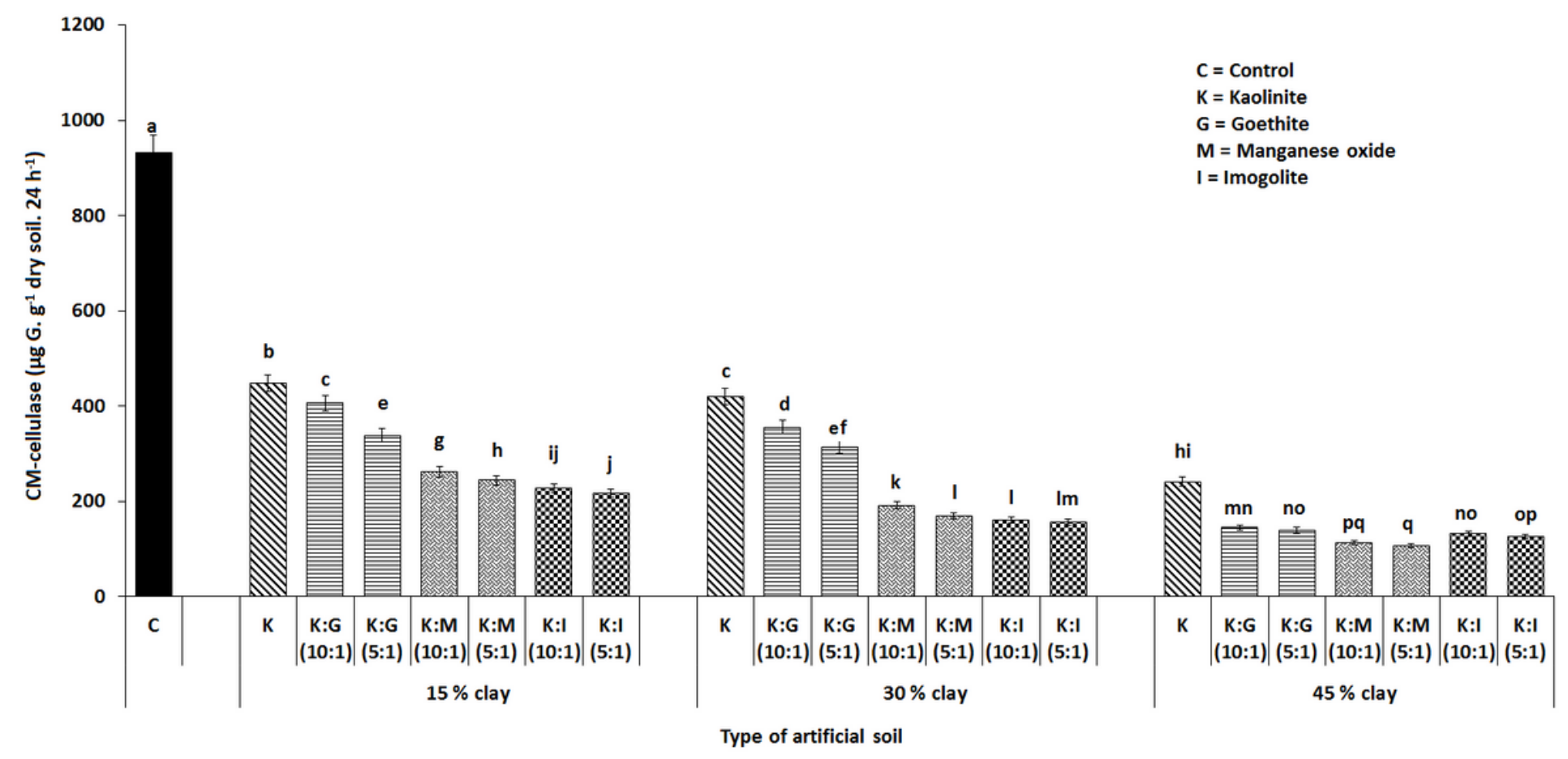

Figure 6

Caption not included with this version. 

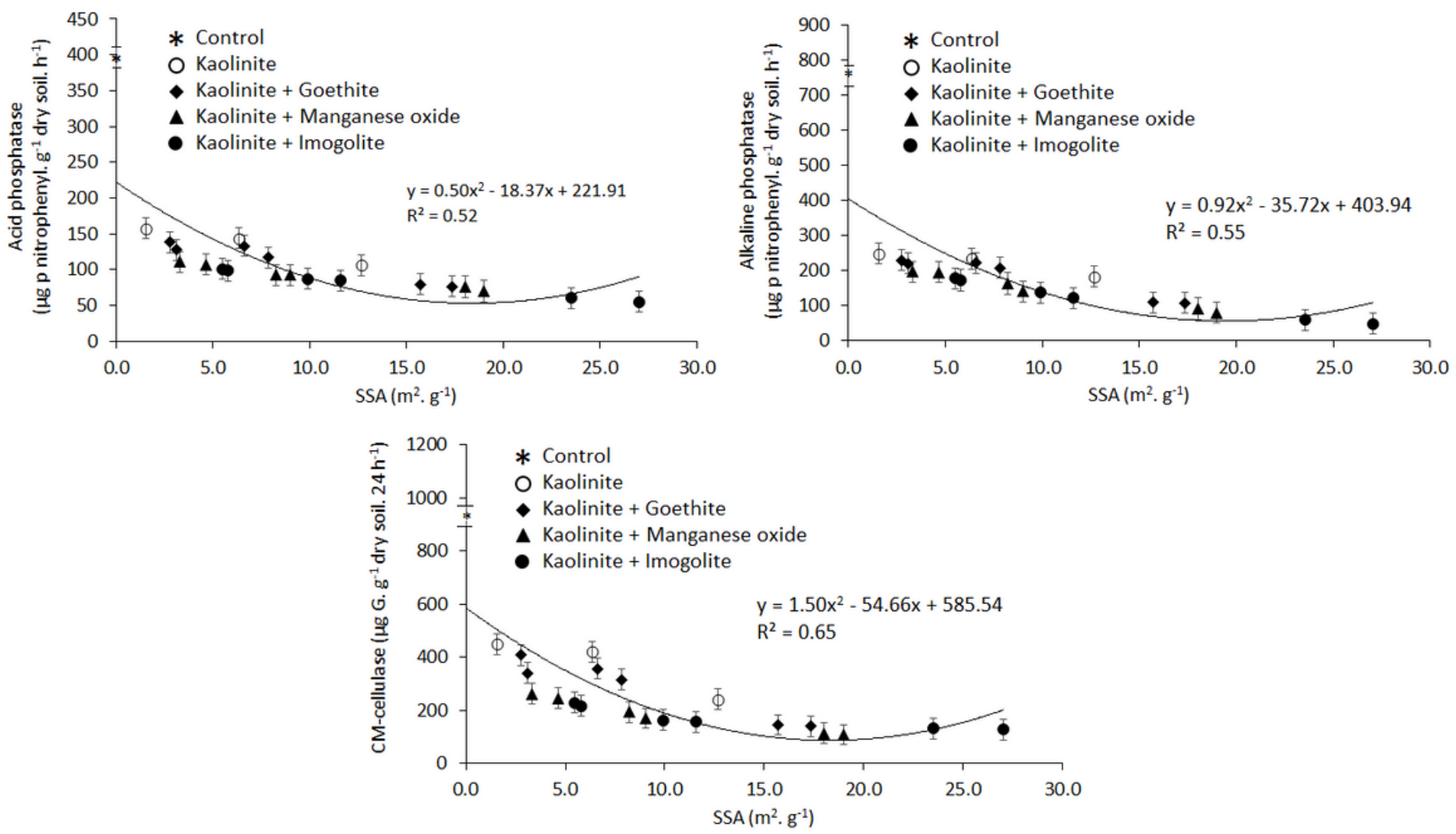

Figure 7

Caption not included with this version.

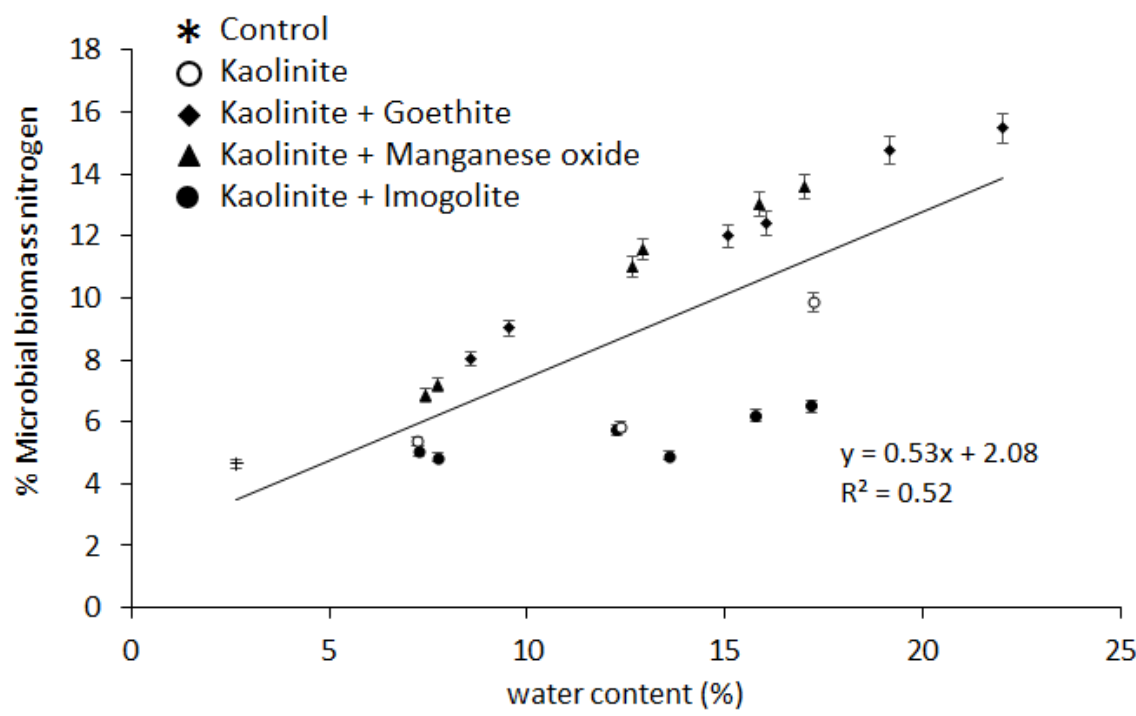

Figure 8

Caption not included with this version.

\section{Supplementary Files}

This is a list of supplementary files associated with this preprint. Click to download. 
- Fig.S1.tif

- Fig.S2.tif

- Fig.S3.tif

- Highlights.docx

- TableS1.docx

Page 13/13 